Klin. Wschr. 54, 947-956(1976)

Klinische

Wochen-

schrift

(C) by Springer-Verlag 1976

\title{
Histamine and Peptic Ulcer: A Prospective Study of Mucosal Histamine Concentration in Duodenal Ulcer Patients and in Control Subjects Suffering from Various Gastrointestinal Diseases*
}

\author{
H. Troidl, W. Lorenz, H. Rohde, G. Häfner, and M. Ronzheimer** \\ Surgery Clinic and Division of Experimental Surgery and Pathological Biochemistry of the University of Marburg, Marburg (Lahn)
}

\section{Histamin und Ulkuskrankheit}

Zusammenfassung. In einer prospektiven Studie wurde der Histamingehalt der Korpusschleimhaut bei 100 Patienten gemessen. Diese Patienten schließen Kontrollpersonen, Ulkus-duodeni-Träger und solche mit verschiedenen gastrointestinalen Erkrankungen ein. Der Histamingehalt betrug $43 \mu \mathrm{g} / \mathrm{g}$ bei Kontrollpersonen und war bei Ulkus-duodeni-Kranken signifikant um 30\% erniedrigt. Alle anderen Patientengruppen wiesen ,normale" Histamingehalte in der Magenschleimhaut auf. Da es bei allen Säugerarten mit Ausnahme der Ratte äußerst schwierig ist, den Histamingehalt der Magenschleimhaut durch irgendeine Maßnahme $\mathrm{zu}$ verändern, erscheint die $\mathrm{Ab}$ nahme des Histamingehaltes der Korpusschleimhaut beim Ulkus duodeni besonders bemerkenswert. Unter verschiedenen Hypothesen gilt als wahrscheinlichste eine vermehrte Histaminfreisetzung beim chronischen Ulkus duodeni.

Schliisselwörter: Histamingehalt - Magenschleimhaut - Ulkus duodeni - Gastrointestinale Erkrankungen - Histaminfreisetzung.

Summary. In a prospective study the histamine content of the mucosa of the body of the stomach was measured in 100 patients consisting of control subjects, patients with duodenal ulcer and patients suffering from various gastrointestinal diseases. The histamine content was found to be $43 \mu \mathrm{g} / \mathrm{g}$ in male control subjects (median) while in duodenal ulcer patients levels attained were significantly lower by about 30 per cent. In all the other groups of patients histamine concentrations in gastric mucosa were found to be "normal". Since in most species it is extremely diffi-

\footnotetext{
* Presented at the meeting on "Gastric and duodenal ulcer disease: Basic principles and clinics of treatment by drugs and operations", Marburg, November 22, 1975

** Supported by the Deutsche Forschungsgemeinschaft (Lo 199/5)
}

cult to alter the mucosal histamine concentration by any form of treatment, the diminished histamine content of the gastric mucosa in patients with duodenal ulcer seems remarkable. Among several possible explanations offered for this finding we think the most likely is that histamine release is increased in duodenal ulcer disease.

Key words: Histamine content - Gastric mucosa Duodenal ulcer - Gastrointestinal disease - Histamine release.

Clinical observations and experimental findings alike justify the hypothesis that nervous and humoral stimulants of gastric acid secretion are factors in the pathogenesis of chronic duodenal ulcer disease. Three basic arguments, for instance, have been advanced in favour of a role played by the vagus nerve (Dragstedt, 1962): continuous hypersecretion is observed in human duodenal ulcer disease; vagotomy abolishes the fasting hypersecretion and heals ulcers. Similar arguments can be found for a role for the family of gastrins, since continuous infusion of pentagastrin produces ulcers in cats (Konturek et al., 1973) and hypergastrinaemia in the Zollinger-Ellison syndrome is accompanied by peptic ulcer disease (Ellison and Wilson, 1964).

Histamine has long been a candidate for inclusion in this exclusive club of ulcer-promoting factors (Babkin, 1950). Thus chronic or continuous application of histamine produces ulcers in animals (Büchner et al., 1928; Walpole et al., 1940). When gastrin was isolated, however, histamine went out of fashion in gastric physiology (Johnson, 1971) and for a time it seemed that the vagus and gastrin were, together, sufficient to account for the genesis of peptic ulcers. Interest in histamine was re-awakened by the intro- 
duction of histamine $\mathrm{H}_{2}$-receptor antagonists by Black et al. (1972, 1973). These drugs inhibit both fasting and stimulated gastric secretion and promote the healing of peptic ulcers in man (multicentre trial, 1975). The interpretation of these findings is still disputed, however, and not necessarily has to include histamine as a physiological or pathophysiological intermediary in the stimulation of gastric secretion (Grossman and Konturek, 1973). Certainly, the arguments in favour of a role for histamine-namely that histamine induces ulcers in animals and that $\mathrm{H}_{2}$-receptor antagonists heal duodenal ulcers in man-appear just as cogent as the arguments advanced in favour of the gastrins and the vagus.

Certain conditions have to be satisfied, in our opinion, before histamine can be accepted as an aetiological factor in duodenal ulcer disease: (1) histamine alone or in combination with other gastric secretory stimulants should be shown to produce experimental ulcers, (2) in the gastric mucosa around the parietal cells, free histamine should occur continuously in concentrations higher than normal in order to induce fasting hypersecretion, (3) in the duodenum, free histamine should be present as in gastric mucosa, contributing to the pathogenesis of peptic ulcer by influencing the release of inhibitory hormones such as secretin, and by altering the microcirculation. Histamine has been shown to be capable of releasing gastrin (Fielding et al., 1974), insulin (Vance and Bragg, 1969) and pituitary hormones (Harris et al., 1952) and its actions on the microcirculation have been studied intensively (Schayer, 1961).

There are several speculative mechanisms by which free histamine levels might be elevated around the parietal cell: (1) increased plasma histamine concentrations may occur in liver insufficiency and portacaval shunting, but have been demonstrated conclusively only in acute situations such as after drug administration and operations (Lorenz et al., 1972; Lorenz et al., 1974; Lorenz, 1976), (2) histamine may be released from gastric mast cell stores in abnormally large amounts by gastric stimulants, (3) enhanced formation of (induced?) histamine may be elicited by various nervous and humoral factors (for a review see Lorenz and Pfleger, 1968), (4) finally, the inactivation of histamine may be decreased by influences on histamine methyltransferase activity (Troidl et al., 1973; Barth et al., 1975) or on histamine uptake (Lorenz et al., 1975).

At present it is not possible to measure the concentration of free histamine around human parietal cells in vivo. In order to investigate this problem, however, we have determined the concentration of stored histamine in human corpus mucosa, which may provide a guide to histamine release as it does in certain "acute" situations (Kahlson et al., 1964). A prospective study was therefore performed in 100 patients at our hospital, preliminary results have already been published (Troidl et al., 1976a, 1976b).

\section{Materials and Methods}

\section{Materials}

Design and Protocols of the Study. In a prospective study biopsies of gastric mucosa for histamine estimation were taken in 100 patients from Marburg and surroundings (Nordhessen). The study ran from April 30th, 1973 till September 9th, 1973, and, at the exception of the radiological and microscopical examinations it was carried out exclusively by our working group for gastric disease. This group for the purposes of the study, consisted of two clinical surgeons, two theoretical surgeons (for definition see Lorenz et al., 1976a), four technicians and one medical student.

The various parts of the study (Table 1) were performed in a special suite of rooms, at definite times and always by the same investigators and technicians.

(1) Photostat copies were made of the patients" case histories, which had been completed strictly from data provided by the family doctors and by other hospitals where the patients had previously been treated. In this way no information was lost during the routine work at our clinic. In three cases only earlier findings in other hospitals provided the diagnosis, because due to spontaneous healing of duodenal ulcers the lesions could no longer be demonstrated at our hospital. The clinical questionnaire was completed at our follow-up clinic (Rohde et al., 1976a).

(2) Fibre-gastroscopy was performed by the two clinical surgeons in the morning on Monday and Wednesday each week.

Table 1. Design and protocols of the prospective study on mucosal histamine concentration in various gastric diseases

1. Findings obtained by

- case history (completed by data from other hospitals)

- clinical questionnaire with 60 questions

- oesophago-gastro-duodenoscopy

- microscopical examination of biopsy specimens from oesophagus, stomach and duodenum

- radiology of stomach, intestine and biliary tract

- gastric secretory tests

- operative findings in all cases submitted to surgery

2. Diagnoses established by

- preliminary decision made by two clinical surgeons and by one theoretical surgeon independently of each other

- final decision made by a panel discussion of the three investigators

3. Control subjects and patients classified by

- present diagnosis

- accompanying diseases

- earlier history

4. Parameters investigated in the study

- Histamine concentration of corpus mucosa

- Basal secretion and maximum secretory response to pentagastrin: ${ }^{2}$ Volume acidity, acid output, pepsin output

a The results on these parameters will be published in forthcoming papers 
All patients submitted to this procedure for diagnostic purposes (none under emergency conditions) were included, without any special selection of cases. By design, also patients with insignificant, but undiagnosed, abdominal complaints were included in the trial so that we might obtain control subjects. The decision in favour of endoscopy, however, in these patients was made by physicians not involved in this study (they belonged to other sections of our clinic or to other departments). There was no seletion of subjects according to the day of the week, so as to have, for example more endoscopies on duodenal ulcer patients on Monday and more in other groups of patients on Wednesday. Hence members of the different groups of patients were likely to have been distributed randomly in our sample, they could so be used as controls for the duodenal ulcer patients because they were subjected to the same physical and psychological stresses. The criterion used to include subjects in the trial was the performance of endoscopy, since in each of a consecutive series of 100 patients submitted to this procedure, biopsy specimens were taken for the determination of mucosal histamine concentration.

(3) Microscopical examination of the biopsy specimens was performed at the Department of Pathology, Marburg, and radiology at a division of our Department of Surgery following a barium meal and administration of iodine benzamic acid (Osbil ${ }^{\oplus}$, BykGulden, Konstanz)

(4) According to the procedure shown in Table 1, the diagnoses were established separately by each of the three investigators.

(5) Following the final decision reached during a panel discussion, the patients were integrated into one of several groups of patients (Table 2) on the basis of the present diagnosis, the accompanying diseases and the diseases found earlier in the case history. Their carlier case history sometimes led to considerable problems in classifying them as "control" or "duodenal ulcer patient". A gastrointestinal disease in earlier life for example might have caused biochemical or morphological alterations in the gastric mucosa which may have continued to exist over the years and influenced the histamine content of the gastric mucosa in this study.

For this and other reasons, 17 subjects were excluded from the study by an escape clause because: (1) they could not be reliably assigned to one of the groups in Table 2 ; (2) several diseases co-existed and none could be definitely identified as the main disease; (3) the case history was incomplete (foreign worker); (4) patients had been submitted to gastric surgery before the start of the trial. Details of each of cases excluded are given in Table 3.

To avoid the introduction of bias the results of the histamine estimations were not recorded until the patients became part of the one or the other group shown in Table 2 .

\section{Definitions of Control Subjects and Patients (Table 2)}

Control Subjects. These patients were considered as "healthy" with respect to their upper gastrointestinal tract. (1) They were submitted to endoscopy for investigation of non-specific abdominal complaints. (2) Disease of the oesophagus, stomach and duodenal bulb could be exciuded by endoscopy and microscopical examination of biopsy specimens. (3) Other diagnostic procedures, such as radiology, clinical investigation and clinical-chemical tests also did not reveal any disease of the upper gastro-intestinal tract like significant hiatal hernia (see below), cholecystitis or pancreatitis. (4) The time-course of their disease excluded an upper gastro-intestinal illness, but like other groups of patients in our study the control subjects fully underwent the emotional stress of the hospital atmosphere. (5) The final diagnoses in the control subjects were: insignificant hiatal hemia (10), constipation (5), dietary indiscretion (3), "nervous stomach" (3), adhesions after appendectomy (3), diseases of rectum (3) [2 carcinomas, 1 haemorrhoids], aorto-femoral bypass (1), sigmoid stenosis (1), umbilical hernia (1), possible trauma of the intestine (1).

Duodenal Ulcer Patients. The diagnosis of duodenal ulceration was established in each patient, usually by all the procedures listed in Table 1, and at least by endoscopic, radiological and histological examination. Accompanying diseases of the upper gastrointestinal tract were excluded but the presence of small and insignificant hiatal hernias was ignored for purposes of classification.

Gastric Ulcer Patients. In all cases the diagnosis was established not only by endoscopy, radiology and histology but also by operation and intra-operative frozen section microscopical examination (to exclude carcinoma!).

Hiatal Hernia Patients. Hiatal hernia of insignificant degree are considered as an anomaly frequently occurring with more or less

Table 2. Attributes of "control subjects" and patients included in the trial. The ages of female control subjects ranged from 24 to 76 years. 5 patients who were not operated upon and 12 following gastric surgery were not included and are described in Table 3

\begin{tabular}{|c|c|c|c|c|c|}
\hline \multirow[t]{2}{*}{ Diagnoses } & \multirow{2}{*}{$\begin{array}{l}\text { Number } \\
\text { of subjects } \\
\text { investigated }\end{array}$} & \multicolumn{2}{|l|}{ Sex } & \multirow{2}{*}{$\begin{array}{l}\text { Age (Range) } \\
\text { (years) }\end{array}$} & \multirow{2}{*}{$\begin{array}{l}\text { Weight (Range) } \\
(\mathrm{kg})\end{array}$} \\
\hline & & Male & Female & & \\
\hline Control subjects & 31 & 21 & 10 & $17-81$ & $69-110$ \\
\hline Duodenal ulcer & 18 & 17 & 1 & $19-74$ & $47-96$ \\
\hline Gastric ulcer & 10 & 9 & 1 & $39-87$ & $47-61$ \\
\hline Hiatal hernia & 6 & 2 & 4 & $53-84$ & $57-93$ \\
\hline Gastric carcinoma & 5 & 5 & 0 & $43-78$ & $48-75$ \\
\hline Cholecystitis & 4 & 0 & 4 & $35-60$ & $65-80$ \\
\hline Gastric erosions & 3 & 2 & 1 & 25.66 & $52-84$ \\
\hline Zollinger-Ellison Syndrome & 1 & 1 & 0 & 36 & 50 \\
\hline Atrophic gastritis & 1 & 0 & 1 & 72 & 52 \\
\hline Pancreatitis & 1 & 1 & 0 & 17 & 95 \\
\hline $\begin{array}{l}\text { Oesophageal varices due to } \\
\text { portal vein cavernoma }\end{array}$ & 1 & 1 & 0 & 27 & 65 \\
\hline Alimentary obesity & 2 & 2 & 0 & $24 ; 32$ & $144 ; 155$ \\
\hline Total & 83 & 61 & 22 & $17-87$ & $47-155$ \\
\hline
\end{tabular}


Table 3. Attributes and mucosal histamine concentrations of patients excluded from the trial by escape clause. $\delta=$ male; $q=f$ female, - means "no significant disease". Concerning the criteria for exclusion, see text in section 1 of Materials and Methods. Vagotomy= selective gastric vagotomy and pyloroplasty, B I or B I = Billroth I or II enteroanastomosis, 2/3-resection and antrectomy, all operations as described by Seidel et al. (1973), patients after operation came to our follow-up clinic

\begin{tabular}{|c|c|c|c|c|c|c|c|}
\hline \multirow[t]{2}{*}{ Name } & \multirow[t]{2}{*}{ Sex } & \multirow{2}{*}{$\begin{array}{l}\text { Age } \\
\text { (years) }\end{array}$} & \multirow{2}{*}{$\begin{array}{l}\text { Weight } \\
(\mathrm{kg})\end{array}$} & \multicolumn{3}{|l|}{ Diagnoses } & \multirow{2}{*}{$\begin{array}{l}\text { Mucosal hista- } \\
\text { mine content } \\
(\mu \mathrm{g} / \mathrm{g})\end{array}$} \\
\hline & & & & present & accompanying & earlier & \\
\hline \multicolumn{8}{|c|}{ Patients not operated (escape criteria 1-3) } \\
\hline B.F. & $\hat{\sigma}$ & 39 & 65 & Scar in duodenal bulb & Unknown & Unknown & 30.4 \\
\hline B.P. & $\delta$ & 43 & 72 & Chronic liver disease & Atrophic gastritis & - & 14.4 \\
\hline Schw.W. & $\pi$ & 43 & 68 & Oesophagitis ulcerosa & Pancreatitis & - & 28.7 \\
\hline Sch.H. & $\tilde{\sigma}$ & 36 & 91 & Intrapyloric ulcer & - & Cholecystitis & 78.7 \\
\hline W.H. & $\delta$ & 17 & 95 & Duodenal ulcer & Pancreatitis, alcoholism & - & 40.3 \\
\hline
\end{tabular}

Patients having undergone gastric surgery (escape criterion 4)

\begin{tabular}{|c|c|c|c|c|c|c|c|}
\hline E.K. & 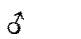 & 35 & 87 & Vagotomy & - & Duodenal ulcer & 63.5 \\
\hline K.K. & $\delta$ & 41 & 62 & Vagotomy & - & Duodenal ulcer & 51.6 \\
\hline K.M. & 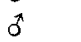 & 67 & 56 & Vagotomy & - & Duodenal ulcer & 47.9 \\
\hline R.H. & $\hat{f}$ & 35 & 72 & Vagotomy & cholecystitis & Duodenal ulcer & 102.0 \\
\hline Sch.J. & $d$ & 68 & 74 & Vagotomy & - & Duodenal ulcer & 49.7 \\
\hline T.A. & $\delta$ & 67 & 69 & Vagotomy & - & Duodenal ulcer & 68.8 \\
\hline P.E. & $\hat{\delta}$ & 43 & 75 & Recurrent ulcer (vagotomy) & - & Duodenal ulcer & 35.0 \\
\hline C.M. & $\hat{0}$ & 47 & 50 & Vagotomy + antrectomy (B II) & - & Duodenal ulcer & 70.7 \\
\hline T.E. & $\hat{\sigma}$ & 52 & 62 & 2/3-resection (B I) & - & Gastric ulcer & 63.5 \\
\hline G.J. & $\delta$ & 48 & 63 & Reoperation (B II) & - & Jejunal ulcer & 9.8 \\
\hline N.A. & 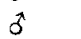 & 71 & 56 & 2/3-resection (B II) & Cholecystectomy & Gastric ulcer & 57.0 \\
\hline Sch.R. & 우 & 45 & 72 & 2/3-resection (B II) & - & Duodenal ulcer & 41.1 \\
\hline $\begin{array}{l}\text { Total: } \\
17 \text { patients }\end{array}$ & $\begin{array}{c}16 \% \\
10\end{array}$ & $17-71$ & $50-95$ & $\begin{array}{l}12 \text { operated, } \\
7 \text { vagotomies, } \\
5 \text { gastric resections }\end{array}$ & $\begin{array}{l}4 \text { patients with } \\
\text { significant accompanying } \\
\text { diseases }\end{array}$ & $\begin{array}{l}\text { Operations } \\
\text { mainly for } \\
\text { duodenal ulcer }\end{array}$ & $9.8-102.0$ \\
\hline
\end{tabular}

remarkable complaints (Salter, 1975). Thus this diagnosis was only accepted for classification in patients if it was thought very likely to be the dominant reason for the abdominal complaints. The complaints, especially during the night (Earlam, 1976), had to be so intense as to render treatment mandatory. The diagnosis of hiatal hernia was made using data from the case history, clinical examination, endoscopy and radiology (Salter, 1975).

Other Groups of Patients. The diagnosis and classification were accomplished by the method outlined in Table 1, as well as by common clinical-chemical tests. The diagnosis of Zollinger-Ellison syndrome was established by the finding of elevated basal serum gastrin levels on 6 occasions, increase in serum gastrin levels following secretin injection and calcium infusion, and of elevated basal serum gastrin levels following total gastrectomy (radioimmunoassay of gastrin was performed by R. Arnold, M.D., Department of Internal Medicine, University of Göttingen).

Preparation of Biopsy Specimens. The panendoscope $7089 \mathrm{P}$ from ACMI (Wappler, Munich) was used, with straight optics and a biopsy forceps with a spike $(2.9 \mathrm{~mm})$, in a modification of type $7035 \mathrm{~A}$. The jaws of the forceps were longer $(3.9 \mathrm{~mm})$ and deeper $(0.9 \mathrm{~mm})$ than the original type so that larger biopsies could be obtained. Four biopsy specimens were taken from the body mucosa of each of the subjects. Three of them were used for mucosal histamine determination and one for microscopical examination. The samples for histamine assay were weighed immediately after withdrawal on a microbalance (Sartorius, Type 2774) and suspended each in $4 \mathrm{ml} 0.4 \mathrm{M} \mathrm{HClO}_{4}$. Until histamine determination these mixtures were kept at $-20^{\circ} \mathrm{C}$ in a deep-freezer for no longer than two weeks.

Drugs and Reagents. Before endoscopy, the patients drank 1-2 ml SAB-Simplex ${ }^{\circledast}$ (Parke-Davis) dissolved in $50 \mathrm{ml}$ tap water $(0.6 \mathrm{ml}$ SAB-Simplex ${ }^{\circledR}$ contained $40 \mathrm{mg}$ dimethylpolysiloxane, $0.1 \mathrm{mg}$ sodium saccharin, $1.2 \mathrm{mg}$ sodium cyclamate). As premedication 15 min before starting endoscopy, the patients were given i.v atropine $(0.01 \mathrm{mg} / \mathrm{kg})$, hyoscine- $\mathrm{N}$-butylbromide $(0.3 \mathrm{mg} / \mathrm{kg})$, triflupromazine hydrochloride $(0.15 \mathrm{mg} / \mathrm{kg})$ and diazepam $(0.1 \mathrm{mg} / \mathrm{kg})$. None of these drugs caused significant histamine release which might have lowered gastric histamine concentration (Lorenz et al., 1974). Only the substances described by Lorenz et al. (1972a, 1974 a) were used, as reagents in order to exclude impurities interfering with the assay. Twice-distlled water was prepared in a quartz still (Köttermann Ltd.).

\section{Methods}

Fluorometric Assay of Histamine in Biopsy Specimens

Histamine was determined according to a modification of our Dowex-method (Lorenz et al., 1970). The modification was necessary in order to increase the sensitivity of the assay for measuring the amine only in a few milligrams of tissue (Lorenz et al., 1975). The perchloric acid mixtures containing the biopsy specimens were homogenised with an Ultraturrax homogenizer using a microshaft TP $10 \mathrm{~N}$. The total homogenate which showed a consistency of 
turbid water was applied to the Dowex columns without prior centrifugation but only after adjustment to $\mathrm{pH} 6.5$ by $5 \mathrm{M} \mathrm{NaOH}$ and $0.1 \mathrm{M}$ sodium phosphate buffer ( $\mathrm{pH} 6.5$ ). After elution of histamine from the columns, condensation with $0.1 \% \mathrm{o}$-phthaldialdehyde was carried out to lower the reagent blanks and to increase the sensitivity of the assay (Lorenz et al., 1976 b). Thanks to a new photomultiplier used (Lorenz et al., 1974a), very small slide widths could be applied on the Zeiss fluorometer. Histamine was expressed as $\mu \mathrm{g}$ histamine dihydrochloride/g.

Miscellaneous Techniques to Ensure Precision and Accuracy of the Histamine Determination. A fourth sample was obtained for microscopical examination from the area where the three biopsy specimens were taken for histamine assay. This enabled to assess the depth of the mucosal sample and to establish the pathological diagnosis. The techniques involved are described by Rohde et al. (1976b). The precision and accuracy of the histamine determination were tested both within the same day and from day to day (quality control). The results of these studies were published in detail elsewidths could be applied on the Zeiss fluorometer. Histamine was expressed as $\mu \mathrm{g}$ histamine dihydrochloride/g.

Statistical Methods. Since the frequency distribution of the mucosal histamine contents in duodenal ulcer patients diverged considerably from normal, the median-percentile system was used for parameters of location and variance. Significance was tested by means of the Mann-Whitney-U test, which is suitable for non-parametric data (Sachs, 1974).

\section{Results}

\section{Histamine Concentrations in Body Mucosa of Control Subjects}

In 31 control subjects, the histamine content of the body mucosa was $40.7(31.4-46.1) \mu \mathrm{g} / \mathrm{g}$ fresh weight (median, 1st-3rd quartile). This is a very high hista-

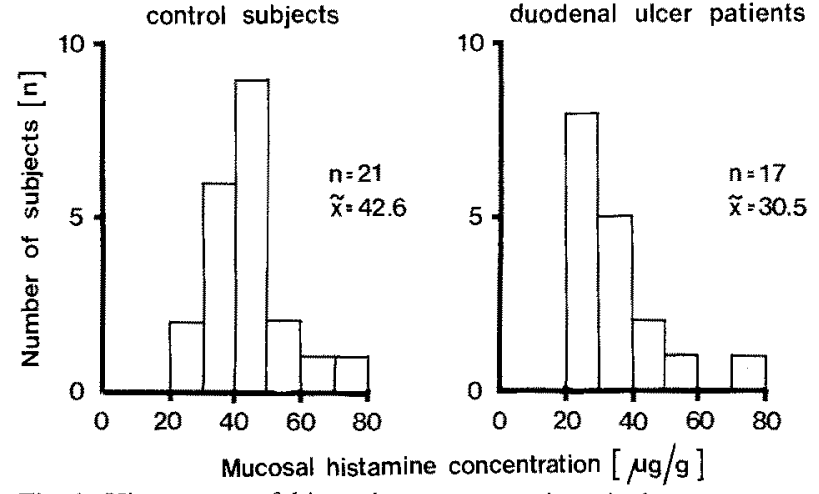

Fig. 1. Histograms of histamine concentrations in human corpus mucosa of control subjects and duodenal ulcer patients. Only male subjects were included. $\tilde{x}=$ median. Statistical significance (MannWhitney test) between the two groups of individuals $p<0.025$

mine concentration compared to that of other human tissues (Lorenz et al., 1973). The values were fairly normally distributed, as shown in Figure 1 for male subjects, but the same was true for the whole sample of "normal" subjects. There existed no obvious correlation between histamine levels and age, though the small number of subjects in the different groups may not have been sufficient for reliable calculation of statistical significance (Table 4).

In male control subjects the mucosal histamine content attained $42.6(31.4-49.6) \mu \mathrm{g} / \mathrm{g}(n=21)$ and in female controls $35.8(24.5-46.3) \mu \mathrm{g} / \mathrm{g}(n=10)$. The difference of $16 \%$ between males and females was not statistically significant.

Table 4. Histamine concentrations in human corpus mucosa of control subjects and duodenal ulcer patients depending on age. Only male subjects were included. Statistical significance (Mann-Whitney test) between the two groups of individuals: ${ }^{*} p<0.1, * * p<0.2$

\begin{tabular}{|c|c|c|c|c|c|c|c|}
\hline \multirow[t]{2}{*}{ Diagnosis } & \multirow[t]{2}{*}{$n$} & \multirow[b]{2}{*}{$<20$} & \multicolumn{5}{|c|}{ Histamine content $(\mu \mathrm{g} / \mathrm{g})$} \\
\hline & & & $20-34$ & $35-49$ & $50-64$ & $65-79$ & $>79$ years \\
\hline $\begin{array}{l}\text { Control } \\
\text { subjects }\end{array}$ & $\begin{array}{l}1 \\
2 \\
3 \\
4 \\
5 \\
6 \\
7 \\
8\end{array}$ & 33.5 & $\begin{array}{l}22.7 \\
30.3 \\
40.9 \\
44.4 \\
45.7 \\
45.9 \\
46.3 \\
51.2\end{array}$ & $\begin{array}{l}23.2 \\
31.4 \\
37.8 \\
40.7 \\
49.5 \\
55.6\end{array}$ & $\begin{array}{l}35.6 \\
41.1\end{array}$ & $\begin{array}{l}31.8 \\
61.0 \\
76.8\end{array}$ & 43.3 \\
\hline Median & & - & $45.1 *$ & $39.3^{* *}$ & 38.3 & 61.0 & - \\
\hline $\begin{array}{l}\text { Patients } \\
\text { with } \\
\text { duodenal } \\
\text { ulcer }\end{array}$ & $\begin{array}{l}1 \\
2 \\
3 \\
4 \\
5 \\
6 \\
7\end{array}$ & 71.5 & $\begin{array}{l}21.7 \\
24.5 \\
37.6 \\
38.1 \\
42.5\end{array}$ & $\begin{array}{l}22.3 \\
23.1 \\
25.0 \\
26.3 \\
29.8 \\
47.7 \\
51.4\end{array}$ & $\begin{array}{l}24.0 \\
30.5 \\
33.8\end{array}$ & 26.7 & - \\
\hline Median & & - & 37.6 & 26.3 & 30.5 & - & - \\
\hline
\end{tabular}




\section{Histamine Concentrations in Corpus Mucosa of Patients with Chronic Duodenal Ulcer}

In this group of patients values can be presented only for male subjects, since there was only one woman. The mucosal histamine content in 17 males was 30.5 (24.0-42.5) $\mu \mathrm{g} / \mathrm{g}$ (median, 1st-3rd quartile). The frequency distribution of the histamine values, however, was far from normal (Fig. 1) and corresponded more to a log-normal distribution. By the Mann-Whitney test, the mucosal histamine concentration in duodenal ulcer patients was found to be significantly by $30 \%$ lower $(p<0.025)$ than in male control subjects (Fig. 1).

As in control subjects there was no detectable correlation between mucosal histamine content and age in duodenal ulcer patients (Table 4). It seemed remarkable however that these two groups of individuals were really well matched for age. The difference in the mucosal histamine content between the two groups of patients could be demonstrated in all age groups which contained more than one individual (Table 4). Since the two groups of subjects were also well matched for weight, it seems fair to conclude that the difference in mucosal histamine concentration between "normal" control subjects and duodenal ulcer patients was well established.

The only female duodenal ulcer patient in our trial also had a prepyloric gastric ulcer (Dragstedt combination). Her mucosal histamine content was relatively high $(81 \mu \mathrm{g} / \mathrm{g})$. No conclusions can be drawn since we have no further experience of mucosal histamine levels in this disease in women.

\section{Histamine Concentrations in Corpus Mucosa of Patients with Various Gastric Diseases}

With the exception of one patient suffering from a Zollinger-Ellison syndrome, all other groups of patients showed mucosal histamine concentrations higher than those found in duodenal ulcer patients (Table 5).

For direct comparison with the values in other groups of patients, the histamine concentrations in the 9 male subjects with gastric ulcer should be noted: 33.8 (32.8-47.4) $\mu \mathrm{g} / \mathrm{g}$ (median, 1st-3rd quartile). The only female subject with a gastric ulcer showed a mucosal histamine concentration of $28.8 \mu \mathrm{g} / \mathrm{g}$.

Patients with significant hiatal hernia were not different from "normal" control subjects with respect to their mucosal histamine content. Patients with cholecystitis (females only) had slightly higher values. Patients with gastric cancer (male subjects only) had slightly lower values than those found in the control
Table 5. Histamine concentrations in human corpus mucosa of patients suffering from various gastro-intestinal diseases. Male and female subjects were included. Due to the small number of individuals in the groups only for histamine values of male gastric ulcer patients statistical significance could be calculated in comparison to control subjects and duodenal ulcer patients. Using the MannWhitney test in none of the two cases the differences were significant which should not be expected from the small number of patients (cf. those for control subjects and duodenal ulcer patients)

\begin{tabular}{lrll}
\hline Diagnosis & $n$ & \multicolumn{2}{l}{ Histamine content $(\mu \mathrm{g} / \mathrm{g})$} \\
\cline { 3 - 4 } & & $\begin{array}{l}\text { Median or } \\
\text { single values }\end{array}$ & Range \\
\hline Gastric ulcer & 10 & 37.2 & $15.5-98.8$ \\
Hiatal hernia & 6 & 37.2 & $13.4-66.8$ \\
Gastric carcinoma & 5 & 38.3 & $20.8-70.7$ \\
Cholecystitis & 4 & 48.0 & $31.7-71.0$ \\
Gastric erosions & 3 & 43.0 & - \\
Z.E. syndrome & 1 & 13.3 & - \\
Atrophic gastritis & 1 & 95.8 & - \\
Pancreatitis & 1 & 40.3 & - \\
Oesophageal varices & 1 & 63.0 & - \\
Obesity & 2 & $40.9,45.7$ & - \\
\hline
\end{tabular}

subjects (Table 5). The single cases of Zollinger-Ellison syndrome and of atrophic gastritis which have widely differing gastric histamine levels, do not permit to draw a definite conclusion and further investigation is needed.

Finally, in the patients of the "escape" group (Table 3) histamine concentrations were in generally considerably higher than those in duodenal ulcer patients. Mucosal histamine contents after vagotomy, in particular were found to be even higher than those observed in "normal" control subjects. This interesting result has been confirmed in a second prospective study to be published elsewhere in greater detail (Troidl et al., 1976b).

\section{Discussion}

\section{Reliability of the Findings on Mucosal Histamine Concentrations in Various Groups of Patients with Gastrointestinal Disease}

There were three main problems which influenced the reliability of our results on mucosal histamine concentration: reliability of the histamine assay in biopsy specimens, relative thickness of mucosal biopsies and reliability of allotting patients to the various groups.

Using a modification of the fluorometric method for histamine determination in tissues (Lorenz et al., 1970), this amine could be determined in all gastric biopsy specimens investigated (Lorenz et al., 1975; 
Lorenz et al., 1976b). The specificity of the assay has been assured by the usual tests of identity (Lorenz, 1975; Lorenz et al., 1976), while the precision and relative accuracy of this technique have been shown by carrying out quality control experiments within the day and from day to day (Lorenz et al., 1975; Rohde et al., 1976b). There is thus no doubt about the reliability of the histamine assay in biopsy specimens.

As shown by our group (Rohde et al., 1976b) and others (Heinkel et al., 1960; Kobayashi et al., 1974) the relative thickness of mucosal particles obtained by biopsy varies considerably. Only in $18 \%$ of the specimens was the total thickness of the mucosa reached. In $55 \%$, two-thirds, and in $27 \%$, one-third of the body mucosa were obtained. This problem however seemed to be solved by taking three biopsy specimens from each of the subjects, so minimising the possibility that only superficial parts of the gastric mucosa were taken, since the relative thickness of mucosal particles was randomly distributed in the same patients. Furthermore, histamine and mast cells containing histamine (see below) have been found to be fairly uniformly distributed throughout the thickness of the mucosa (Murray and Wyllie, 1964; Håkanson et al., 1970) or to have some degree of preference for the more superficial layers of the body mucosa (Smith, 1959; Räsänen, 1958).

The third problem, i.e., establishing the diagnoses and to group patients into the various groups with sufficient accuracy, represented the greatest source of difficulty in our trial. Initially it seemed very simple to define and to establish the diagnosis of a duodenal ucler, but for a variety of reasons it proved to be difficult in individual cases (Troidl et al., 1975). Similar comments have been made by Goligher et al. (1972). In addition the detection of accompanying diseases and a critical evaluation of their significance was very laborious and always contained an element of subjectivity and personal bias. The previous history of a patient sometimes contained conflicting information which made it difficult to include him in a distinct group in our trial. For example, can a patient be considered to be a "normal" control subject if he has had significant "gastritis" for a relatively long period several years ago? In our panel discussion a new dimension was introduced by the realisation that, aside from other attributes, human beings differ from guinea-pigs mainly by their personal histories! On account of all these difficulties it was important that the values for the mucosal histamine concentrations should be added to the other data of each individual patient only after the final decision had been made about his belonging to one or another group in our trial.

\section{Histamine Concentrations in Human Gastric Mucosa: Alteration in Duodenal Ulcer Disease and Hypotheses about its Cause and Clinical Significance}

In this investigation mucosal histamine concentrations were determined in a relatively large number of human subjects. Samples of gastric mucosa were taken under more favourable conditions (i.e. closer to normal physiological conditions) than has been the case in all other previous studies. This enabled us to conclude at a relatively high reliability that the histamine content in "normal" human gastric mucosa was indeed very high and that it was significantly different from normal in duodenal ulcer disease. Since in any species except the rat (Kahlson et al., 1964) it is extremely difficult to alter the mucosal histamine concentration by any treatment (cf. Lorenz and Pfleger, 1968) the decrease in histamine content in duodenal ulcer disease seems to be remarkable.

To our knowledge, histamine in human gastric mucosa is localized exclusively in mast cells. Studies using fluorescent microscopy have shown that cells in this tissue which emit luminescence after treatment with o-phthaldialdehyde were always mast cells if the sections were consecutively stained with toluidine blue (Håkanson et al., 1969). These observations were in contrast to the findings of Tobe and Tanaka (1972) who described histamine-induced fluorescence coming from parietal cells they did not exclude the possibility that the fluorescence which they observed originated from mast cells closely related to parietal cells (toluidine blue staining was not done!) (Lorenz et al., 1971). According to Räsänen (1958) the highest density of mast cells in human corpus mucosa is indeed found in the layers which also show the highest density of parietal cells. His finding that there is a lower density of "detectable" mast cells in duodenal ulcer patients than in normal subjects provides support for our results (Räsänen, 1958).

Histamine in mast cells is stored histamine which has been predominantly measured in our study. The finding of a decrease in stored histamine in duodenal ulcer disease first led to the hypothesis that this might be due to an augmented histamine liberation in this disease. In short-term experiments indeed a decrease of tissue histamine content reflects histamine release, mast cell degranulation and occurrence of the amine in body fluids (Lorenz et a1., 1973a; Lorenz et al., 1974b). Similar results were obtained from rat gastric mucosa where histamine is not secreted from mast cells but from enterochromaffin-like cells (Kahlson et al., 1964; Thunberg, 1967; Håkanson et al., 1967; Lundell, 1974). Since duodenal ulcer disease is a chro- 
nic long-lasting process, our hypothesis is not (entirely) convincing, but nevertheless remains as a possible explanation for our findings.

There is good evidence that duodenal ulcer disease is associated with increased vagal activity (Dragstedt, 1962). In rats vagally stimulated gastric secretion is accompanied by histamine release from gastric mucosa (Kahlson et al., 1967; Thunberg, 1967). Although the bulk of this histamine may be derived from enterochromaffin-like cells, a part of it may also be liberated from the "atypical" mast cell in the more superficial layers of gastric mucosa (Thunberg, 1967; Aures et al., 1968), because vagally stimulated gastric secretion is indeed inhibited after degranulation of mucosal mast cells in rats (Hirvonen et al., 1967). Mast cell degranulation furthermore is observed in experimental gastro-duodenal ulcers produced by stress in rats (Guth and Hall, 1968; Guth and Kozbur, 1968, 1969) and this process is largely blocked by vagotomy. None of these arguments provides clear evidence of vagally stimulated histamine release in human subjects-in particular, in duodenal ulcer patients-but they do not exclude the possibility that our hypothesis of an augmented histamine release in duodenal ulcer disease might be correct. It would then be expected that the mucosal histamine content of duodenal ulcer patients increase after vagotomy, which does in fact happen (Troidl et al., 1975a, 1975 b). This finding increases the chances that our hypothesis is correct.

A second hypothesis to explain our findings is that of decreased histamine formation in duodenal ulcer disease. It is difficult to accept this idea at present for the following reasons. Firstly, it is by no means accepted that histamine be formed in human gastric mucosa (Lorenz et al., 1976c). The existence of a specific histidine decarboxylase in human gastric mucosa has been both accepted and denied. The existence of a non-specific histidine decarboxylase has been shown by all investigators so far but its physiological significance has been frequently questioned (for a review of the arguments, see Lorenz et al, 1976c). Secondly, the only species which possesses a high activity of specific histidine decarboxylase in gastric mucosa is the rat. In that species vagal stimulation does not depress histamine formation but enhances histidine decarboxylase activity (Kahlson et al., 1967; Thunberg, 1967). Thus the hypothesis seems unconvincing that histamine formation is decreased in duodenal ulcer disease.

A third hypothesis is that there exists an increased inactivation of gastric histamine in duodenal ulcer disease. Barth et al. (1977) however found that histamine methyltransferase activity -the only enzyme at present known to inactivate histamine in human gastric mucosa-is significantly diminished in the corpus mucosa of duodenal ulcer patients. Thus this hypothesis also lacks conviction.

The effects of histamine $\mathrm{H}_{2}$-receptor antagonists, metiamide and cimetidine on healing duodenal ulcers (multicentre study, 1975) could be explained by two different mechanisms, namely in that (1) it prevents abnormally large amounts of histamine to be released at the $\mathrm{H}_{2}$-receptors of the parietal cells. (2) or that it activates histamine methyltransferase in gastric mucosa which, in turn, leads to faster inactivation of the released histamine. In vitro this effect was shown by Barth et al. (1973, 1973a). In vivo there are findings which support this hypothesis (Thjodleifsson and Wormsley, 1975).

\section{References}

1. Aures, D., Håkanson, R., Schauer, A. : Histidine decarboxylase and DOPA decarboxylase in the rat stomach. Properties and cellular localization. Europ. J. Pharmacol. 3, 217 (1968)

2. Babkin, B.P.: Secretory mechanisms of the digestive glands, P.B. Hoeber, New York, 1950, p. 547

3. Barth, H., Lorenz, W., Troidl, H.: Effect of modiaquine on gastric histamine methyltransferase and on histamine-stimulated gastric secretion. Brit. J. Pharmacol. 55, 321 (1975)

4. Barth, H., Niemeyer, I., Lorenz, W.: Studies on the mode of action of histamine $\mathrm{H}_{1}$ - and $\mathrm{H}_{2}$-receptor antagonists on gastric histamine methyltransferase. Agents and Actions 3, 138 (1973)

5. Barth, H., Niemeyer, I., Lorenz, W. : Studies on the mechanism of inhibition of gastric histamine methyltransferase by $\mathrm{H}_{1}-$ and $\mathrm{H}_{2}$-receptor antagonists. In: Int. Symp. on Histamine $\mathrm{H}_{2}-\mathrm{Re}$ ceptor Antagonists, C.J. Wood, M.A. Simkins, (eds.), Deltakos (UK), London, p. 115 (1973a)

6. Barth, H., Troidl, H., Lorenz, W., Rohde, H.: Histamine and peptic ulcer disease: Histamine methyltransferase activity in gastric mucosa of control subjects and duodenal ulcer patients Agents and Actions (in press) (1977)

7. Black, J.W., Duncan, W.A.M., Durant, G.J., Ganellin, C.R., Parsons, M.E.: Definition and antagonism of histamine $\mathrm{H}_{2}$ receptors. Nature (London) 236, 385 (1972)

8. Black, J.W., Duncan, W.A.M., Emmet, J.C., Ganellin, C.R., Hessellbo, T., Parsons, M.E, Wyllie, J.H. : Metiamide - an orally active histamine $\mathrm{H}_{2}$-receptor antagonist. Agents and Actions 3, $133(1973)$

9. Büchner, F., Siebert, P., Molloy, P.J.: Über experimentell erzeugte akute peptische Geschwüre des Rattenvormagens. Beitr. pathol. Anat. 81, 391 (1928/1929)

10. Dragstedt, L.R.: Section of the vagus nerves to the stomach in the treatment of duodenal ulcer. In: Surgery of the stomach and duodenum (Harkins, H.N., Nyhus, L.M. (eds.)), Little, Brown and Company, Boston, p. 461 (1962)

11. Earlam, R.: Clinical tests of oesophageal function. Crosby Lockwood Staples, London, p. 342 (1976)

12. Ellison, E.H., Wilson, O.: The Zollinger-Ellison Syndrome: Re-appraisal and evaluation of 260 registered cases. Ann. Surg. 160, $512(1964)$

13. Fielding, L.P., Curwain, B.P., Russell, R.C.G., Bloom, S.: Evidence for separate actions of an adrenergic $\beta_{2}$ stimulant and an histamine- $\mathrm{H}_{2}$ blocker on the oxyntic and gastrin cells. Brit. J. Surg. 62, 157 (1975) 
14. Goligher, J.C., Pulvertaft, C.N., Irvin, T.T., Johnston, D., Walker, B., Hall, R.A., Willson-Pepper, J., Matheson, T.S.: Five to eight years results of truncal vagotomy and pyloroplasty for duodenal ulcer. Brit. med. J, I, 7 (1972)

15. Grossman, M.I., Konturek, S.J.: Inhibition of acid secretion in dog by metiamide a histamine antagonist acting on $\mathrm{H}_{2-}$ receptors. Intern. Symp. on Histamine $\mathrm{H}_{2}$-receptor Antagonists (Wood, C.J. and Simkins, M.A. (eds.), Deltakos (UK) Itd., London), 1973, p. 297

16. Guth, P.H., Hall, P.: Microcirulatory and mast cell changes in restraint induced gastric ulcer. Gastroenterology 50, 562 (1966)

17. Guth, P.H., Kozbur, X.: Pathogenesis of gastric microcirculatory and mast cell changes in restraint stress. Amer. J. dig. Dis. 13, 530 (1968)

18. Guth, P.H., Kozbur, X.: Microcirculatory and mast cell changes in restraint stress. Amer. J. dig. Dis. 14, 113 (1969)

19. Harris, G.W., Jacobson, D., Kahlson, G.: The occurrence of histamine in cerebral regions related to the hypophysis. Ciba found. Coll. on Endocr, 4, 186 (1952)

20. Håkanson, R., Owman, Ch., Sjöberg, N.-O., Sporrong, B.: Amine mechanisms in enterochromaffin and enterochromaffinlike cells of gastric mucosa in various mammals. Histochemie 21, 189 (1970)

21. Hảkanson, R., Lilja, B., Owman, Ch.: Cellular localization of histamine and monoamines in the gastric mucosa of man. Histochemie 18, 74 (1969)

22. Håkanson, R., Lilja, B., Owman, Ch.: Properties of a new system of amine-storing cells in the gastric mucosa of the rat. Europ. J. Pharmacol. 1, 188 (1967)

23. Heinkel, K., Tomat, E., Henning, N.: Meßergebnisse über die Dicke der Magenfundusschleimhaut im bioptischen Material. Klin. Wschr. 38, 1032 (1960)

24. Hirvonen, J., Kamppuri, V., Räsänen, T.: Inhibition of vagally stimulated gastric secretion after mucosal mast cell degranulation. Acta physiol. scand. 70, 236 (1967)

25. Johnson, L.R.: Control of gastric secretion: no room for histamine? Gastroenterology 61, 106 (1971)

26. Kahlson, G., Rosengren, E., Svahn, D., Thunberg, R.: Mobilization and formation of histamine in the gastric mucosa as related to acid secretion. J. Physiol. (London) 174, 400 (1964)

27. Kahlson, G., Rosengren, E., Thunberg, R. : Accelerated mobilization and formation of histamine in the gastric mucosa evoked by vagal excitation. J. Physiol, (London) 190, 455 (1967)

28. Konturek, S.J., Demitrescu, T., Radecki, T., Dembinski, A.: Effect of metiamide, a histamine $\mathrm{H}_{2}$-receptor antagonist on gastric and pancreatic secretion and peptic ulcers induced by histamine and pentagastrin in cats. Intern. Symp. on Histamine $\mathrm{H}_{2}$-Receptor Antagonists, C.J. Wood, M.A. Simkins (eds.), Deltakos (UK) Ltd., London, 1973, p. 247

29. Kobayashi, S., Kasugai, T.: Endoscopic and biopsy criteria for the diagnosis of esophagitis with a fiberoptic esophagoscope. Amer. J. dig. Dis. 19, 345 (1974)

30. Lorenz, W.: Histamine release in man. Agents and Actions $5,402(1975)$

31. Lorenz, W., Pfleger, K. : Stoffwechsel und physiologische Funktion von Histamin im Magen. Klin. Wschr, 46, 57 (1968)

32. Lorenz, W., Bennesch, L., Barth, H., Matejka, E., Meyer, R., Kusche, J., Hutzel, M., Werle, E.: Fluorometric assay of bistamine in tissues and body fluids: choice of the purification procedure and identification in the nanogram range. $Z$. anal. Chem. 252, 94 (1970)

33. Lorenz, W., Schauer, A., Reimann, H.-J.: Biochemical and histochemical studies on the histamine stores in the pig. Naunyn-Schmiedebergs Arch. Pharmakol. 269, 416 (1971)

34. Lorenz, W., Doenicke, A., Meyer, R., Reimann, H.-J., Kusche, J., Barth, H., Geesing, H., Hutzel, M., Weissenbacher, G.:
Histamine release in man by propanidid and thiopentone: Pharmacological effects and clinical consequences. Brit. J. Anaesth. 44, 355 (1972)

35. Lorenz, W., Reimann, H.-J., Barth, H., Kusche, J., Meyer, R., Doenicke, A., Hutzel, M.: A sensitive and specific method for the determination of histamine in human whole blood and plasma. Hoppe-Seylers Z. physiol. Chem. 353, 911 (1972a)

36. Lorenz, W., Matejka, E., Schmal, A., Seidel, W., Reimann, H.-J., Uhlig, R., Mann, G.: A phylogenetic study on the occurrence and distribution of histamine in the gastrointestinal tract and other tissues of man and various animals. Comp. gen. Pharmacol. 4, 229 (1973)

37. Lorenz, W., Thermann, M., Hamelmann, H., Schmal, A., Maroske, D., Reimann, H.-J., Kusche, J., Schingale, F., Dormann, P., Keck, P.: Influence of $\mathrm{H}_{1}$ - and $\mathrm{H}_{2}$-receptor antagonists on the effects of histamine in the circulatory system and on plasma histamine levels. Int. Symp. on Histamine $\mathrm{H}_{2}$-Receptor Antagonists (C.). Wood, M.A. Simkins (eds.)), Deltakos (UK), London, p. 151 (1973a)

38. Lorenz, W., Seidel, W., Doenicke, A., Tauber, R., Reimann, H.-J., Uhlig, R., Mann, G., Dormann, P., Schmal, A., Häfner, G., Hamelmann, H.: Elevated plasma histamine concentrations in surgery: Causes and clinical significance. Klin. Wschr. 52 , 419 (1974)

39. Lorenz, W., Barth, H., Thermann, M., Schmal, A., Dormann, P., Niemeyer, I.: Fluorometric histamine determination in canine plasma at normal conditions, following application of exogenous histamine and during histamine release by Haemaccel $^{\text {(e) }}$ Hoppe-Seylers Z. physiol. Chem. 355, 1097 (1974a)

40. Lorenz, W., Thermann, M., Messmer, K., Schmal, A., Dormann, P., Kusche, J., Barth, H., Tauber, R., Hutzel, M., Mann, G., Uhlig, R.: Elevation of histamine elimination curves in plasma and whole blood of several circulatory regions: a method for studying kinetics of histamine release in the whole animal. Agents and Actions 4, 336 (1974b)

41. Lorenz, W., Troidl, H., Rohde, H., Häfner, G.: Histamine content in human gastric mucosa: reliability of its determination in biopsy specimens. Abstr. 6th Intern. Congress of Pharmacology, Helsinki (1975), R 20

42. Lorenz, W., Troidl, H., Schulz, S., Becker, H., Dormann, P., Sehmal, A., Meyer, R., Kusche, J., Barth, H., Rohde, H.: Stimulus-secretion coupling in the human and canine stomach: role of histamine Intern. Conf. on Stimulus-secretion coupling in the Gastrointestinal Tract, (R.M. Case and H. Goebell (eds.), MTP press, Lancaster 1976 p. 177

43. Lorenz, W., Hamelmann, H., Troid1, H.: Surgical research in Marburg: A five-year experience of cooperation between clinical and theoretical surgeons. Klin. Wschr. 54, 927 (1976a)

44. Lorenz, W., Rohde, H., Troidl, H., Schwarz, B., Schmal, A.: Histamine determination in biopsy specimens of human gastric mucosa. Hoppe-Seylers Z. physiol. Chem. (in preparation) (1976b)

45. Lorenz, W., Barth, H., Kusche, J., Troid1, H., Rohde, H., Schmal, A., Stenner, W., Nusimé, H., Häfner, G., Glass, R., Friedrich, A.: A critical review concerning metabolism and physiological function of histamine in the gastric mucosa. Satellite Symp. on Gastrointestinal Hormones, Krakow, October 1974 (in press) (1976c)

46. Lundell, L.: Acid secretion and mobilization of gastric mucosal histamine on combined cholinergic and pentagastrin stimulation. Agents and Actions 4, 211 (1974)

47. Multicentre Trial: Treatment of duodenal ulcer by metiamide. Lancet ii, 779 (1975)

48. Murray, J.G., Whyllie, J.H.: Distribution of histamine, 5-hydroxy-tryptamine, and other pharmacologically active substances in the human stomach. Gut 5, 530 (1964)

49. Räsänen, T.: Tissue eosinophils and mast cells in the human 
stomach wall in normal and pathological conditions. Acta path. microbiol. scand. Suppl. 129, 1 (1958)

50. Rohde, H., Troidi, H., Lorenz, W.: Assessment of a series of defined attributes and parameters before and after vagotomy: A concept for evaluation of operative results in duodenal ulcer patients. Europ. Surg. Res. (in press) 1976a

51. Rohde, H., Lorenz, W., Troidl, H., Reimann, H.-J., Häfner, G.: Precision and accuracy of histamine determination in human biopsy specimens. Clin. chim. Acta (in preparation) (1976b)

52. Sachs, L.: Angewandte Statistik. Planung und Auswertung, Methoden und Modelle. 4th edition, Springer, Berlin, Heidelberg, New York p. 230 (1974)

53. Salter, R.H.: Common gastroenterological problems: sliding hiatus hernia. Practitioner 214, 264 (1975)

54. Schayer, R.W.: Significance of induced synthesis of histamine in physiology and pathology. Chemotherapia 3, 128 (1961)

55. Seidel, W., Troidl, H., Lorenz, W., Rohde, H., Richter, H., Drews, H., Hamemann, H.: Eine prospektive, kontrollierte Studie zur selektiven Vagotomie beim chronischen Duodenalulkus: Frühergebnisse mit einer standardisierten Operationsauswahl und Operationstechnik. Klin. Wschr. 51, 477 (1973)

56. Smith, A.N.: Distribution and release of histamine in human gastric tissue. Clin. Sci. 18, 32 (1959)

57. Thunberg, R.: Localization of cells containing and forming histamine in the gastric mucosa of the rat. Exp. Cell. Res. 47, 108 (1967)

58. Tobe, T., Tanaka, Ch.: Histamine containing cells in the human gastric mucosa. Histochemical study using microscopic spectrofluorometry. Amer. J. Gastroent. 58, 133 (1972)

59. Thjodleifsson, B., Wormsley, K.G.: Aspects of the effect of metiamide on pentagastrin-stimulated and basal gastric secretion of acid and pepsin in man. Gut 16, 501 (1975)
60. Troidl, H., Lorenz, W., Barth, H., Rohde, H., Feifel, G., Schmal, A., Goecke, K., Reimann-Huhnd, A., Seidel, W.: Augmentation of pentagastrin stimulated gastric secretion in the Heidenhain pouch dog by amodiaquine : inhibition of histamine methyltransferase in vivo? Agents and Actions 3, 157 (1973)

61. Troidl, H., Lorenz, W., Rohde, H., Häfner, G., Ronzheimer, M., Schmal, A.: Histamine content in human gastric mucosa: Its relation to pentagastrin-stimulated acid secretion and to selective gastric vagotomy. Agents and Actions 5, 427 (1976a)

62. Troidl, H., Rohde, H., Lorenz, W.: Histamine concentrations in gastric mucosa of duodenal ulcer patients before and one year after selective gastric vagotomy. Brit. J. Surg. 63, 155 (1976)

63. Troidl, H., Lorenz, W., Rohde, H., Fischer, M., Hamelmann, H.: Was ist gesichert in der Behandlung der Ulcuskrankheit durch Vagotomie? Internist (Berl.) 16, 575 (1975)

64. Vance, J.W., Bragg, S.C. : Insulin release in response to microvasoactive substances. Diabetes 18, Suppl. 1, 326 (1969)

65. Walpole, St.H., Varco, R.L., Code, C.F., Wangensteen, O.H.: Production of gastric and duodenal ulcers in the cat by intramuscular implantation of histamine. Proc. Soc. exp. Biol. Med. 44, $619(1940)$

Priv. Doz. Dr. H. Troidl

Chirurgische Univ.-Klinik

Robert-Koch-Str. 8

D-3550 Marburg a.d. Lahn

Federal Republic of Germany 